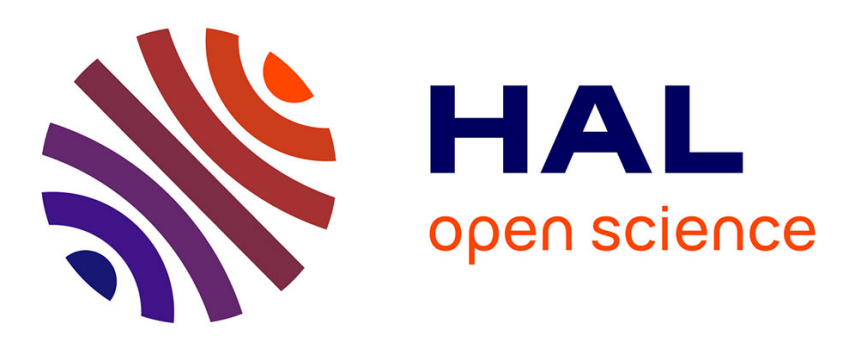

\title{
From Preaching to Investing: Attitudes of Religious Organisations Towards Responsible Investment
}

Céline Louche, Daniel Arenas, Katinka C. van Cranenburgh

\section{To cite this version:}

Céline Louche, Daniel Arenas, Katinka C. van Cranenburgh. From Preaching to Investing: Attitudes of Religious Organisations Towards Responsible Investment. Journal of Business Ethics, 2012, 110 (3), pp.301-320. 10.1007/s10551-011-1155-8 . hal-01098144

HAL Id: hal-01098144

https://hal-audencia.archives-ouvertes.fr/hal-01098144

Submitted on 23 Dec 2014

HAL is a multi-disciplinary open access archive for the deposit and dissemination of scientific research documents, whether they are published or not. The documents may come from teaching and research institutions in France or abroad, or from public or private research centers.
L'archive ouverte pluridisciplinaire HAL, est destinée au dépôt et à la diffusion de documents scientifiques de niveau recherche, publiés ou non, émanant des établissements d'enseignement et de recherche français ou étrangers, des laboratoires publics ou privés. 


\title{
From preaching to investing: Attitudes of religious organisations towards responsible investment
}

Céline Louche, Vlerick Management School

Daniel Arenas, ESADE Business School, Ramon Llull University

Katinka C. van Cranenburgh, ESADE Business School, Ramon Llull University

\begin{abstract}
Religious organisations are major investors with sometimes substantial investment volumes. An important question for them is how to make investments in, and to earn returns from, companies and activities that are consistent with their religious beliefs or that even support these beliefs. Religious organisations have pioneered responsible investment. Yet little is known about their investment attitudes. This article addresses this gap by studying faith consistent investing. Based on a survey complemented by interviews, we investigate religious organisations' attitudes towards responsible investment including opinions, practices and the impediments for implementing faith consistent investing. Although our results cannot be generalised because of the non-random character of our sample, six main characteristics of faith consistent investing are drawn: investing is not perceived as being in contradiction with religious values, religious values are important drivers, there is a strong community around faith consistent investing, religious investors are pioneering impact investing, implementing faith consistent investing is not without difficulties, and practices vary across regions. The survey also reveals that faith consistent investing has many commonalities with secular responsible investors.
\end{abstract}




\section{Introduction}

Religions have always expressed a concern about how to harmonise the values they preached and the realities of commercial or business activity. More concretely, their concern about how to combine ethical virtues and different investment practices goes back at least several hundred years (Domini, 2001). For example, efforts to reconcile religious beliefs and investment can be traced in the Jewish doctrine of 3,500 years ago or in the Catholic tradition with regard to the practice of taking interest on a loan and in other types of contracts: 'if equality is not maintained, whatever is received over and above what is fair is a real injustice' (Benedict XIV, 1745).”

Religious organisations, especially in Europe and North America, are important investors with sometimes substantial investment volumes. It seems therefore reasonable and legitimate for religious organisations to raise and address the question of how to make investments in, and to earn returns from, companies and activities that are consistent with their religious beliefs or that even support these beliefs. As a result, religious organisations have pioneered modern forms of responsible investment (RI) (Kreander et al., 2004; Sparkes and Cowton, 2004) in that they believed that investing was not a neutral activity, but implied values. For example, they shunned "sinful" companies whose products conflicted with their basic beliefs. The 1999 Trend Report of the US Social Investment Forum stated:

"In the mid-1900s, the founder of Methodism, John Wesley, emphasized the fact that the use of money was the second most important subject of New Testament teachings. As Quakers settled North America, they refused to invest in weapons and slavery" (US SIF, 1999).

In 1971 the Methodists in the US established the Pax World Fund which avoided investment in businesses involved in armaments, alcohol and gambling. Also, Islamic banking and finance has grown rapidly in the last years (Kinder and Domini, 1997; Schwartz, 2003; Statman, 2005; Kettell, 2008).

Although the significant role played by religious organisations in the field of RI has been recognised by practitioners and academics, little is known about their investment beliefs and practices. RI in general has gained considerable attention in the literature, but the focus has mainly been on the financial performance of RI funds (e.g.Diltz, 1995; Statman ,2000; Bauer et al., 2005; Barnett and Salomon, 2006; Bauer et al., 2007; Amenc and Le Sourd, 2010), the operation of RI funds (e.g. Sparkes and Cowton, 2004; Graaf et al., 2009; Sandberg et al., 2009), RI investors' behaviour (e.g.Anand and Cowton, 1993; Lewis and Mackenzie, 2000; Lewis, 2001; Keller and Siegrist, 2006; Glac, 2009), shareholder engagement (e.g. Hoffman, 1996; Graves et al., 2001; Clark and Hebb, 2004; Clark et al., 2008) and on the information stream (e.g. Nilsson et al., 2010; Rhodes, 2010). This reflects the general lack of research into 
religious organisations investment and accounting practices (Booth, 1993; Duncan et al., 1999; Kreander et al., 2004).

This paper addresses this gap by studying the attitudes of religious organisations towards responsible investment. Attitudes can be defined as "learned predispositions to respond in a consistently favourable or unfavourable manner with respect to a given object'" (Fishbein and Ajzen, 1975), or in other words as a positive or negative evaluation of an object of thought. Attitudes are abstractions; they are hypothetical or latent variables rather than an immediately observable variable (Green, 1953). According to Green (1953), the concept of attitude does not refer to any one specific act or response of an individual, but it is an abstraction from a large number of related acts or responses. In this paper we study the opinions and practices of religious organisations towards investing in general and more especially towards responsible investing. Opinions and practices are both expressions of attitudes (Katz, 1960), one being verbal and the other behavioural. Opinions refer to the cognitive component of attitude, that is the thoughts and beliefs people hold about the object of the attitude, while practices refer to the behavioural component of attitude, that is the dispositions to act in certain ways toward an attitude object (Breckler, 1984; Crites et al., 1994; Ostrom, 1969; Rodrigo and Arenas, 2008). In this paper, religious organisations' attitudes are investigated through a survey. This study brings insights into not only an important RI player but also one of largest groups of investors in the world ${ }^{1}$ that can play a significant role in creating change towards sustainability through their investment practices.

The paper is structured as follows. First, it reviews background on RI and its link to religious organisations. Second, it presents the methodology of the study. Third, it details the results of the survey and the main findings. In the final section, it provides conclusions and discussions in which research and managerial implications are outlined.

\section{Background}

\section{Responsible Investment}

Although there is considerable debate as to what truly constitutes RI (Cowton, 1994; Sparkes, 1995; Cowton, 1998; Sparkes, 2001), it can be described as a product, a practice and a process (Louche and Lydenberg, 2011). Responsible investment is an investment product in the sense that in addition to financial factors, investors acquire, hold, or dispose of companies' shares on the basis of environmental, social, governance (ESG) factors as well as ethical factors. It is a practice in the sense that RI is a way to identify companies with strong corporate social

\footnotetext{
${ }^{1}$ According to His Excellence Mr Ban Ki-moon, United Nations Secretary-General, speech at the Celebration of Faiths and the Environment in Windsor in November 2009.
} 
responsibility (CSR) records and to engage with companies to encourage improved CSR performance. And RI is a process through which investors try to influence corporations' behaviour on a range of social, environmental and ethical issues.

Responsible investment manifests itself in many ways and, not surprisingly, goes by many names - it is variously referred to as socially responsible investing, ethical investing, sustainable investing, triple-bottom-line investing, green investing, best-of-class investing, ESG (environmental, social, and governance) investing, impact investing, and most simply and more recently responsible investing. These different names reflect in part the evolution of the RI field over time. If RI started as a marginal movement in the United States several hundred years ago, today it is known and practiced throughout the world. Although precise figures are difficult to come by, there has been a significant growth of assets under RI management since the late early 2000s. In the United States, RI assets under management were at $\$ 3.07$ trillion in 2010, representing 12.2 percent of the $\$ 25.2$ trillion in total assets under management (US SIF, 2010). RI assets increased by 380 percent from 1995 to 2010. In Europe from 2002 to 2010, RI asset under management has been multiplied by almost 15 . Eurosif has placed the value of the RI market at $€ 5$ trillion as of December 31, 2009 (Eurosif, 2010). However its understanding, practices and the actors involved have changed over time. Louche and Lydenberg $(2010 ; 2011)$ have identified five phases in the development of RI.

- Roots phase, $18^{\text {th }}$ Century. This is the very early stage of RI. The main actors were religious institutions.

- Development phase, 1970s to late 1980s. This phase marks the beginnings of RI in the contemporary sense of the term during which RI was transformed from a faith-based activity into an activity promoting a public awareness of the social responsibility of corporations (the self-conscious phenomenon of RI) (Sparkes, 2001). During this phase $\mathrm{RI}$ is particularly driven by political and protest movements of that time such as the anti-Vietnam War and anti-apartheid in South Africa (Louche and Lydenberg, 2006). In the 1980s, RI also took root in Europe (The Friends Provident Stewardship Unit Trust in 1984). Simultaneously, a number of RI support organisations were created, such as the Interfaith Center on Corporate Responsibility (ICCR) in 1971.

- Transition phase, 1990s. During the early 1990s, RI began a gradual transition to a less confrontational approach with a strong growth in environmental concerns. During this period emerged the so-called green funds, especially in Europe. This period also saw the number of social rating agencies and RI indexes grow rapidly.

- Expansion phase, 2000s. The beginning of the twenty-first century heralded a turning point for RI in both its approach and its growth. Professionalisation and growth characterise this period. RI began to find acceptance in the mainstream investment community, leaving behind its more activist image and becoming a more commercially viable endeavour (Déjean et al., 2004; Louche, 2004).

- Mainstreaming phase? 2010s. Around 2010 RI stood at a crossroads. Its increasing acceptance by institutional investors was marked by such events as the launch of the 
Principles for Responsible Investment (PRI) in 2006. By 2010, the PRI had grown into a coalition of more than 800 of the largest institutional investors and asset managers worldwide, representing some \$22 trillion under management. This current period could well mark the mainstreaming of RI.

Gradually the role of religious organisations in the different phases became less and less dominant to become secondary today. Religious origins are still found in the secular RI community, although their presence is less obvious. As RI has been adopted by mainstream financial institutions, they have become the main actor both in the discourse and practices of RI but also in academic research. Nonetheless religious organisations are still active RI actors through what we call in this paper Faith Consistent Investing (FCI). Networks like ICCR and $3 \mathrm{iG}$, which promote responsible investment among religious organisations, are quite representative of the interest of this group of investors.

\section{Religious organisations and RI}

If one wants to study the investments made by religious organisations themselves, it is important to understand the characteristics of religious organisations and to have an historical perspective on the involvement of religious organisations in the activity of responsible investment. We begin by providing a description of religious organisations and then we present the role and engagement of religious organisations in the RI movement.

\section{The nature of religious organisations}

A precise definition of religious organisations can be elusive. Indeed there are different definitions and the scope of the concept might vary creating potential problems for interpretation. As expressed by an Israeli Internal Relations Professor talking about Jerusalem:

"The question is: what is a religious institution? Is it just a church or also a monastery or a hospital? Is it just a synagogue or also a private mikve [ritual pool] or yeshiva [Talmudic academy]? Is it a church library, a church-run women's club? What about other Christian denominations, the Muslims, the Druze and Bahai? There is no end to it. In the 'Holy Land', everything is someone's religious institution.” (Cohen, 2010)

In short, what constitutes a religious organisation is not self-evident. Even within a religion, the legal and organisational structure may vary as well as the decision-making process. Those variations are of importance as they may produce different decision making processes and thereby directly influence the practices of religious organisations towards responsible investment. Some religions establish corporations to facilitate business activities, while others operate through unincorporated associations. Even religions as established as the Anglican or Catholic Churches do not have an easily identified legal existence (Gordon Pole, 2005) and 
often consist of multiple organisation forms. For example when considering the Catholic Church, there are at least three kind of organisations one might encounter in the universe of investors: the diocese, the religious order and the non-profit organisations like universities and hospitals. These organisations might be legally subordinate to a bishop or a religious order but also be governed by a lay board of trustees, which is often the case at universities and colleges.

In the field of business ethics, Valor et al. (2007) define 'a religious group' as any religiously inspired organisation, which includes a very broad range of organisations. According to the sociologists Stark and Bainbridge (1987) a religion must be based on some "supernatural assumptions", that is related to things that are not immediately available, to distinguish it from secular thought. In their view religions involve "systems of general compensators based on supernatural assumptions" (1987). By compensators they mean whatever people regard as rewards whether or not they are immediately apparent (Stark and Bainbridge, 1987). Thereby, the core task of religious organisations is the provision of supernatural compensators (e.g. religious doctrines) as well as temporal rewards (e.g. church membership). Another important characteristic of religious organisations based on Durkheim's definition is that they involve collective actions (Durkheim, 2003).

For the purpose of this paper, we have defined religious organisations as organisations whose structure and membership criteria is derived from a certain body of doctrine and belief and are devoted to cultivate among their adherents or followers (and sometimes promote among others) a particular form of religious practice and worship that is expressed in ritual forms. These organisations are clearly distinguished from government, public or private secular associations or institutions and corporations. One could also distinguish them, in a narrow sense, from other institutions that religious organisations may sponsor like NGOs, charity organisations, schools or universities, which are established to realise a specific priority of the religious tradition or mission. Yet, in practice, the boundaries between a narrower and a broader sense of the term are not easily drawn and our study includes both.

\section{Religious investment and responsibility}

The first RI funds were launched by religious organisations both in the United States and in Europe (Louche and Lydenberg, 2006). In the early 1900s in the United Kingdom, the Methodist Church set up a fund that avoided investments in certain sectors and in 1984 Friends Provident, a Quaker-affiliated insurance company, launched its socially screened Stewardship Fund. In Sweden, the Church of Sweden established the Ansvar Aktiefond Sverige in 1965. In France, Nouvelle Strategie Fund, the first RI fund, was launched in 1983 by Nicole Reille, the finance officer of the Notre-Dame Order in Paris. In 1990, the Netherlands saw its first RI fund created by $\mathrm{ABF}$, Het Andere Beleggingsfonds, an initiative of Church groups and environmental movement. In Finland, the Church of Finland was involved in launching the two first ethical funds; in Germany, early ethical funds were launched by local Church banks such 
as the KD Fonds Ökoinvest in 1991. And in the United States, the Methodists and Quakers set up the Pax World Fund in 1971.

Religious organisations also have been very active setting up organisations that have played an instrumental role in the development of RI such as rating agencies. For example, Ethical Investment Research Service (EIRIS) was created in 1983 jointly with the Quakers, the Church of England, the Church of Wales, the Methodists, the Presbyterian Church of Ireland and the Society of Friends and some charities (Mackenzie, 1997). In the US, religious groups initiated the Interfaith Center on Corporate Responsibility (ICCR) in 1971 in response to a concern for the situation in South Africa. In 1972 a group called the Christian Concern for Southern Africa (CCSA) was founded in order to campaign and lobby banks and investors on the apartheid issue. In 2005, the International Interfaith Investment Group 3iG was set up to promote interfaith cooperation in the investment sector.

This brief historical review shows the importance of religious groups in stimulating and launching the field of RI. Their main objective was to put religious beliefs into practice, to harmonise the spheres of values and business, and to use any available tools to have a positive social impact. Because of this specific goal, directly linked to their beliefs, RI practiced by religious organisations is called 'Faith Consistent Investing' (FCI) (Rossetti, 2005). One of the characteristics of FCI has been the "avoidance strategy" or what is also referred to as the exclusion of "sin stocks" such as tobacco, gambling, pornography and alcohol. This approach corresponds roughly to the motivation of avoiding companies engaged in businesses or practices regarded as unacceptable or unethical. The underlying moral principle here is "do no harm".

Today religious organisations are still very active. One needs just to look at religious indexes launched in the last fifteen years such as the FTSE Global Islamic Index Series in 1998, the Dow Jones Islamic Market Index family launched in 1999, the India Islamic Index in 2008, the Dharma Indexes in 2008 or the STOXX Europe Christian Index in 2010. There are also many examples of FCI initiatives taken by religious organisations. The Church of England created in 1994 the Ethical Investment Advisory Group, a group of religious and investment specialists that debate issues relating to the church and ethical investment ${ }^{2}$. The international Roman Catholic Missionary Oblates of Mary Immaculate has set up investment committees on local and central levels to ensure their investment activities are guided by Catholic Social principles. This same religious community uses also very actively its shareholders rights to promote "a more equitable and sustainable world"3. The Union for Reform Judaism resolution of 1997

\footnotetext{
${ }^{2}$ For more information see the Church of England's website, www.cofe.anglican.org/info/ethical, accessed on February 26, 2011.

${ }^{3}$ For more information see OMI Justice and Peace/ Integrity of Creation Office's website, www.omiusajpic.org, accessed on February 26, 2011.
} 
states “.... Socially responsible investment policies and practices are not an optional commitment. They are an organic expression of our core beliefs" $"$. The Protestant Methodist movement has large RI funds through their UK-based Central Finance Board of the Methodist Church $^{5}$ and the US-based General Board of Pension and Health Benefits that supervises and administers retirement plans, investment funds, and health and welfare benefit plans ${ }^{6}$. The USbased National Jesuit Committee on Investment Responsibility, besides having a RI policy for its institution, also calls upon its followers to practice RI, by means of "staying informed, praying, proxy voting and information sharing"?

Despite the historical role of religious organisations in developing RI and the many current FCI activities, little is known about religious organisations attitudes towards responsible investment. Many scholars have studied the role of religion in the broader field of CSR and business ethics (Acquier, 2005; Brammer et al., 2007; Van Buren, 2007; Hui, 2008; Ramasamy et al., 2010; Williams and Zinkin, 2010). A special issue of the Business Ethics Quarterly (Vol. 7, N², March 1997), for example has been devoted to religion and business ethics. But very few have focused on FCI. The few existing studies have a limited scope. Some of them focus on a specific country like Valor and de la Cuesta (2007) who investigated investment demands from religious groups in Spain, or Kreander et al. (2004) who looked at the UK market. Other studies have focused on a specific RI activity like Van Buren (2007) who examined religious shareholder activism in the United States. A third set of studies looked at some specific religions. For example Schwartz et al. (2007) examined RI from a Jewish perspective; Kreander et al. (2004) studied stock market investment practices of the Church of England and UK Methodists; and several articles are focusing on Islamic mutual funds (Naughton and Naughton, 2000; Al-Amine and Al-Bashir, 2001; Archer and Karim, 2002; Delorenzo, 2002; Forte, 2007). To our knowledge, only one study, Ghoul and Karam (2007), made a comparison of Christian, Islamic and RI mutual funds. Finally a last set of research concentrates on issues related to risks, return and performance integrating religious principles in investment strategy (Girard and Hassan, 2008; Hood et al., 2009).

\footnotetext{
${ }^{4}$ For more information see Union for Reform Judaism's website, www.urj.org, accessed on February 26, 2011.

5 For more information see The Central Finance Board of the Methodist Church's website, ww.cfbmethodistchurch.org.uk, Accessed on February 19, 2011.

6 For more information see The Central Finance Board of the Methodist Church's website, ww.cfbmethodistchurch.org.uk, Accessed on February 19, 2011.

${ }^{7}$ For more information see www.jesuit.org, Accessed on February 19, 2011.
} 


\section{Method}

For the purpose of the research we conducted an online survey among religious organisations worldwide and addressed to all types of religions. The next paragraphs present the sample, the questionnaire and the limitations of the study.

\section{Sample}

As mentioned above the aim of this paper is to provide insights into attitudes of religions organisations towards responsible investment. One of our first challenges was to create a database with a broad scope of religious organisations both in terms of geographical spread and religion. To our knowledge, such database does not exist. Two approaches were used to reach our targeted sample.

The first approach was based on Internet search. The aim was to collect contact information from religious organisations around the world. This was done religion by religion. The Internet search led to a database of 316 Christian, 142 Baha'i, 133 Buddhist, 13 Shinto and 13 Hindu representatives of organisations. Through this mean, we managed to create a database of 614 e-mail addresses.

The second approach was more targeted. We asked several Religious Investor Groups (RIGs) around the world to co-operate with us on this research project. Five RIGs responded positively, namely Interfaith Centre for Corporate Responsibility (ICCR) based in the USA, International Interfaith Investment Group (3iG) and Oikocredit based in the Netherlands, the Ecumenical Council for Corporate Responsibility (ECCR) in the UK, and the Shareholder Association for Research and Education (SHARE) in Canada. Many of those organisations have an international reach in terms of members although Anglo-Saxon members remain dominant. Through this second approach the survey was sent to 513 religious organisations' representatives. Databases of the Religious Investor Groups overlapped slightly. As a result some members of the targeted group have received the survey request from several RIGs. Note that only one representative per organisation was allowed to answer.

In the second approach we were sometimes provided with the full database but many times the RIGs sent the survey themselves. Such approach implies losing control on the database as the RIGs took full responsibility in sending the survey and reminders.

In total the survey was sent to 1127 people. However the first approach to reach our targeted sample was not very successful as many of the e-mail addresses were not active anymore and bounced back when we sent the survey or were never opened (459 in total). We have to recognise that Internet sampling may lead to sampling errors and poses special problems for sampling target populations. Internet is vulnerable in inducing invalid response (Best and Krueger, 2004). Therefore we can consider that the survey was sent to 668 people. Based on 
those calculations, we can approximate the response rate at 15.42 percent. The submission period for completing the online survey was from 20th October 2009 to 5th January 2010.

\section{Survey}

\section{Design and testing}

Prior to the survey, we conducted two focus groups on the $16^{\text {th }}$ of July 2009 . In total twenty five representatives from different religions --Jewish, Christian, Islamic-- participated in the focus groups. The representatives were all involved directly or indirectly in the financial management of their respective organisation. The objective of the focus groups was to get insights into the beliefs, practices, gaps, barriers and incentives bearing on faith consistent investing as well as grasping the vocabulary used by religious organisations when talking about RI. The focus groups were tape recorded and transcribed verbatim.

A first draft of the survey was designed based on the inputs from the focus groups and the literature review. The survey was tested on over ten experts, from various institutions, religions and countries. The test group included academics -especially experts in survey designs -, practitioners from religious organisations and experts in responsible investing. The aim was to get detailed feedback on the survey on content, format, length, and style/wording. This feedback was especially important because the questionnaire was to be sent to a very broad range of religious organisations in different countries.

Representatives of the sampled religious organisations were contacted by email and asked to fill in the online questionnaire. The questionnaire was only available in English.

In addition, we had access to $3 \mathrm{iG}$ 's data and knowledge. Throughout the project, from the conception of the survey to the analysis of the results, we had regular discussion with $3 \mathrm{iG}$ 's team and some of $3 \mathrm{iG}$ members. 3iG's insights and experience has been extremely helpful and useful also for the analysis of the results, in order to contextualise, reflect and make sense of the data.

\section{Questionnaire}

The questionnaire was organised in four sections: opinions towards investing, existing RI practices, impediments/facilitators for investing in RI and finally general information on the institution represented and the respondent. The design of the questionnaire was based on previous academic research such as Guyatt (2006), Glac (2008), Lewis and Mackenzie (2000), Schaefer (2004), Juravle and Lewis (2008), and Amaeshi (2010), practitioner reports such as Eurosif (2010) and US SIF (2010) and practices from social rating agencies such as EIRIS, Sustainalytics, and SAM. Valor and de la Cuesta (2007)'s paper has been an important source 
for structuring the questionnaire. Table 1 provides an overview of the variables used to build the questionnaire and the sections below detail the four first dimensions.

\section{Opinions}

Participants were questioned on their opinions about the activity of investing. The objective was to explore the opinions of religious organisations with regard to the activity of investment in general and more especially RI and FCI. Do religious principles prohibit or inhibit investment? Is the activity of investing disconnected from religious believes? Do they perceive potential positive impacts between their investment activities and societal wellbeing? But also are there some RI practices that are more appropriate or acceptable than others?

The representatives of religious organisations were asked to indicate the extent to which they agreed with 16 statements. The statements related to the potential impact of investment practices on society in general, and on business activity in specific. There were also statements linking investment practices and respondents' faith. Last, respondents were asked to state the degree to which they believed they should be active owners of their shares (in other words, to what extent they felt they should be engaged shareholders).

\section{Practices}

In this section, participants were asked about their current investment practices. We investigated four main aspects: negative screening, positive screening, engagement and impact investing. The three first categories represent the three dominant strategies in the RI field. Negative screening refers to the avoidance strategy approach. It seeks to avoid investing in companies engaged in businesses or practices regarded as unacceptable or generally harmful to society. It can be based on the exclusion of certain sectors or of certain activities. Positive screening refers to what is often called 'best-in-class' approach or also relative selection. This approach aims at selecting sector leaders on environmental, social, and governance (ESG) criteria. It invests across all industries and sectors, selecting the best-performing companies in each. It is often based on numerous indicators related to aspects on the environment, corporate governance, business ethics, employees, contractors and customers, and community involvement. The third approach, engagement, refers to shareholder activism or dialogue. It aims at entering into a dialogue with companies and engaging with them to voice shareholders' concerns on ESG and ethical issues. The engagement approach can be done via either confrontational or soft actions.

Impact investing is a new upcoming approach in the field of RI (Cordes, 2010; O'Donohoe et al., 2010; Van Cranenburgh, 2010). The definition in its most simplified way is "investments intended to create positive impact beyond financial return" (O'Donohoe et al., 2010). Impact investing can be described as investments that explicitly aim to solve social or environmental challenges or promote community development while generating financial returns. It focuses on investing solely in initiatives, projects or companies that have a clear and direct positive 
social and environmental impact, rather than industry-benchmarked companies according to certain environmental, social and governance criteria. Religious institutions have historically been at the origin of this approach although, as with their contribution to RI in general, their role tends to be neglected in the literature. For example, the 2010 report co-produced by Global Impact Investing Network (GIIN) and J.P.Morgan (O’Donohoe et al., 2010) does not mention religious organisations at all. Nonetheless Methodists, Catholics, Mennonites, Baptist and Jewish organisations have been involved in impact investing over decades (Bugg-Levine and Goldstein, 2009). While for a long time impact investing did not attract much interest and remained a very marginal activity, these last years the movement is growing and starts to attract a wide range of investors (O'Donohoe et al., 2010). Among religious organisations, some of the most recent examples include the Positive Social Purpose Lending Programme focusing on housing, education, health and microfinance, the Global Solidarity Forestry Fund (forestry in Mozambique), the Catholic Health Initiative and the cleantech and microfinance fund in Paraguay named Sarona Risk Capital Funds. Also on an interfaith basis, religious organisations have joined forces to create social impact, as in the Isaiah Fund, focusing on community development and affordable housing (Van Cranenburgh, 2010).

In total, participants were asked 12 questions, the purpose of which was to supply evidence on the actual investment practices of religious organisations. In addition, information was captured on who makes decisions and whether there are written investment policies.

\section{Impediments/facilitators for investing in RI}

Several studies in the field of RI have focussed on the impediments for responsible investment (Guyatt, 2005; Amaeshi and Grayson, 2006; Guyatt ,2006; Juravle and Lewis, 2008). Jurvale and Lewis (2008) identified three types of obstacles: individual (cognitive biases and belief systems); organisational (internal structures, processes and cultures); and institutional impediments. Examples of this last type are the structure of the investment value chain, regulatory and mimetic pressures on trustees and fund managers, and financial market inefficiencies. Valor et al. (2007) found that "unlike individual investors, institutional investors [they are talking about religious investors, although in a very broad sense] do not think that the main constraint on investing ethically is the lack of economic performance of RI products". It also found that "if offered a product closer to their needs, they would increase the amount invested ethically by over $15 \%$ ". In addition, they identified a lack of information available in the Spanish market as one of the major obstacles. In other words, the main obstacles in that context appeared to be institutional rather than individual or organisational.

Our questions were designed based on those insights. However, the individual types of impediments were left out as it was already tackled in the attitude section. Respondents had to react to 14 statements that explored the factors that may hinder or stimulate change in their investment practices. The objective was to identify barriers and incentives for aligning religious organisations' investment practices and religious beliefs. 
We designed questions about the way respondents perceived the process of FCI. They were asked a series of questions about whether or not they thought they had a control into the way money was invested. For example, this section of the survey included a question about the role of the financial advisor but also questions about their perception of investment products in terms of complexity. They were questioned about the adequacy of the investment products offered, whether or not they were aware of RI and whether or not those products responded to their needs and demands. Some questions addressed the issue of the perceived financial profitability and risks of aligning investment strategies to their faith principles.

In addition participants were asked about the features that could stimulate (or inhibit) FCI in their organisations. The questions addressed aspects related to financial returns, societal impacts, companies' behaviour, and tools available.

In Table 1, we summarise all the factors and dimensions as well as the variables that formed the survey used in this study. We also point to the academic sources that served as references to design the survey.

Table 1 - Overview table of the variables

\begin{tabular}{|c|c|c|}
\hline Factors/Dimensions & Variables & Inspirational sources \\
\hline \multirow[t]{4}{*}{ Opinions towards investing } & $\begin{array}{lcr}\text { Religious } & \text { prohibition or } \\
\text { limitations } & \text { on financial } \\
\text { investment } & & \end{array}$ & \multirow{4}{*}{$\begin{array}{l}\text { Glac (2008), } \\
\text { Lewis \& Mackenzie } \\
(2000), \\
\text { Schaefer (2004) }\end{array}$} \\
\hline & $\begin{array}{l}\text { About impact of investment } \\
\text { on society }\end{array}$ & \\
\hline & About social impact of RI & \\
\hline & $\begin{array}{l}\text { About financial impact of } \\
\text { different RI practices and } \\
\text { strategies }\end{array}$ & \\
\hline \multirow[t]{5}{*}{ Existing RI practices } & Negative screens & \multirow{5}{*}{$\begin{array}{l}\text { Eurosif }(2010 a, b), \\
\text { US SIF }(2010) \text {, } \\
\text { Social rating agencies such } \\
\text { as EIRIS, Sustainalytics, } \\
\text { SAM }\end{array}$} \\
\hline & Positive screens & \\
\hline & Impact investing & \\
\hline & Engagement & \\
\hline & $\begin{array}{l}\text { Responsibilities } \\
\text { leadership }\end{array}$ & \\
\hline
\end{tabular}




\begin{tabular}{|c|c|c|}
\hline & Explicit written policies & \\
\hline \multirow[t]{9}{*}{$\begin{array}{l}\text { Impediments/facilitators for } \\
\text { investing in RI }\end{array}$} & $\begin{array}{l}\text { Organisational (internal } \\
\text { structures, processes and } \\
\text { cultures) }\end{array}$ & \multirow{9}{*}{$\begin{array}{l}\text { Guyatt (2006), } \\
\text { Amaeshi (2010), } \\
\text { Juravle, C. \& Lewis, A. } \\
(2008) \text {, } \\
\text { Valor \& de la Cuesta } \\
(2007)\end{array}$} \\
\hline & Role of financial advisor & \\
\hline & Adequate products available & \\
\hline & Profitability & \\
\hline & Risks & \\
\hline & Evidence of social impact & \\
\hline & $\begin{array}{l}\text { Evidence of change in } \\
\text { company behaviour }\end{array}$ & \\
\hline & Tools available & \\
\hline & Complexity of RI products & \\
\hline
\end{tabular}

\section{Limitations}

The methodological choices and constraints are not without consequences on the results. We would like to discuss three main limitations that are of particular importance when analysing and interpreting the findings.

It is difficult to ascertain how many religious organisations there are in the world. Hence, it is also difficult to know what an appropriate size of sample would be for a study like this. Clearly, the Internet research to identify religious organisations worldwide bore little fruit. This led us using the existing religious investor groups that, by their very nature, included religious organisations that were already interested and involved in FCI. This resulted in a non-random sample; hence, all statements and conclusions should be used with extreme caution. It may be said that this is purposive sampling: the survey was directed to those probably already knowledgeable on the topic.

The second and third points relates to the geographical and inter-religious scope. The second important limitation is language. The study was conducted in English, which has certainly kept potential respondents from participating despite our efforts to try to involve religious organisations in countries like France, Belgium, Spain and The Netherlands. The language was 
a crucial obstacle and limited the geographical spread of the sample. As a result our sample is highly biased towards English speaking countries.

A third limitation is the variety of religions represented in the sample. Although we intended and tried to get a mix of religions, our sample ended up being highly biased towards Christianity, mostly from North America and Western Europe. This bias maybe explained by the networks we used to construct our database, the RIGs. Indeed the RIGs that have helped us with distributing the survey were for most of them based in North America (ICCR, SHARE). The majority of the members of those RIGs are Christians even if they target all faiths. At any rate we should conclude that certain religions are more involved than others in FCI.

Despite these limitations, the survey and its analysis offers a first provisional overview of some of the attitudes of religious organisations towards responsible investment, which will contribute to further studies.

\section{Results}

In this part of the paper we present and analyse the results of the survey. The results are organised into four parts: 'opinions' in which we present what religious organisations think of the activity of investing as well as the appropriateness of the different RI approaches; 'practices' in which we portray the reported RI practices of religious organisations; 'barriers/facilitators' in which we report on the perceived impediments for religious organisations to practice FCI; and 'regional differences' in which we address the issue of regional specificities. Before going into the core of the survey, we start by describing the respondents.

\section{Respondents}

Geographical and religion distribution

Responses were received from 103 organisations, of which 57 were from North America, 22 from Europe, 4 from Africa, 3 from Asia, 1 from Oceania and 16 unknown (as they didn't answer to the question on national origin). The responding organisations can be roughly divided into three main categories which, although different, are all steered by trustees that are expected to guide their organisation in accordance to their religious beliefs: (1) a large majority (78.8\%) were religious institutions with the mission of continuing and spreading their religious beliefs such as churches, diocese, congregations, and orders; (2) a smaller group (12.1\%) consisted of either financial organisations managing directly religious organisation's funds or for a very small number organisations specialised in services to religious organisations with regard to responsible investment; and (3) a last group (9.1\%) represented institutions that are 
religiously inspired but the religion serves as a guide for reaching certain objectives (health / fair trade / education) rather than being the objective in itself.

The majority of respondents (90\%) were of the Christian religion, and within Christianity, most respondents were Catholics (68\%). Out of the 103 respondents, $81 \%$ completed the whole survey. Although we aimed at having a very diversified sample in terms of geographical scope and religions represented, our sample is biased towards one specific religion, namely Christian, and respondents are dominantly from one region of the world, 55\% are form North America. Moreover, the $21 \%$ respondents from Europe are dominantly from the UK. Those indications are important to keep in mind when analysing the data.

\section{Respondents' profile}

$89 \%$ of the respondents were directly involved in the investment decision process within their respective organisations. Although the implementation of the investment policy might often be conducted by investment managers, the respondents of our survey were in charge of the investment policy as their positions in their organisations show: treasurers (17\%), members of the investment committee (16\%), heads of the institution (14\%), members of the board of trustees (13\%), financial advisors (7\%), or theological advisors (2\%). Out of the $31 \%$ mentioning they had another position in their organisation, five were responsible for CSR, four mentioned they were directors, two worked in the area of 'justice' and two contracted for responsible investing. Only $4 \%$ of the religious organisations involved theological advisors (Rabbi, Imam, Monk, Priest et cetera) in investment decisions. In most organisations, investment decisions were made involving several representatives, including boards of trustees (57\%), heads of institutions (20\%), investment committees (69\%), treasurers (37\%) and financial advisors (38\%).

Because religious organisations can be either very centralised or on the contrary very decentralised, we asked the respondents to give us an indication of the geographical scope of their organisation. Most of the religious organisations which answered the survey operated on a country level or beyond (continental or global level). Only $17 \%$ of the respondents indicated they operated on a provincial or village level.

The gender ratio between respondents was fairly even: $52 \%$ were female and $48 \%$ male. With regard to the age distribution, $65 \%$ of respondents answered that they were over 56 . None stated an age under 25 .

\section{Institutional networks}

In the survey, respondents were asked whether or not their institution was member of one or more RIGs or other RI specific networks. Most of the religious organisations that responded to the survey were affiliated to religious investor groups such as the ICCR (66\%), Oikocredit (24\%), 3iG (17\%), ECCR (10\%), CIG (5\%), CCLA (3\%), SHARE/Kairos (6\%). By contrast, 
very few of the organisations were affiliated to secular or general responsible investment initiatives, groups or networks such as Social Investment Fora (SIF) (13\%), the UN Principles of Responsible Investment (UNPRI) (6\%) or the Carbon Disclosure Project (CDP) (7\%).

\section{Opinions}

Opinions on investment activity

In general, the activity of investing did not seem to be in any manner conflicting with religious principles, although $6 \%$ of the respondents felt that they should avoid investing on the stock market altogether. For a large majority, investing and religious principles should not be disconnected. $86 \%$ of the respondents did not see investing as a separated financial matter but indeed wanted their beliefs to be reflected in their investment decisions. Investing neither was regarded as a 'neutral' activity, nor as a way 'to feel good'. Respondents believed that investment was a way to influence corporate behaviour (90\%) and positively impact society $(92 \%)$.

Opinions about investment practices

In general religious organisations did not see any of the RI practices in contradiction with their faith. Be it negative screening, positive screening or engagement, all three approaches were perceived as appropriate. However we found some nuances in the perception of those different approaches.

When integration of religious beliefs into investment decisions was practiced, religious organisations often found it more appropriate to avoid investments in certain activities or products $(86 \%)$, than avoiding companies in certain countries (only 58\% found it an appropriate approach). It seems that country avoidance was a more sensitive issue. This might be due to the fact that avoiding countries can have political impacts beyond religion which can create tension with the concept of separation of church and state, a concept that has been adopted in a number of countries.

Among the engagement approaches, we saw fewer differences. Both the more confrontational and the less confrontational approaches were highly rated (all between 69 and 91\%). However the most confrontational methods like engaging in public debate when in disagreement with the activity of a company or divesting were regarded as slightly less attractive (respectively $78 \%$ and $69 \%$ ) than other strategies.

Our results show that a large majority of the respondents found all the aforementioned strategies appropriate. As we will see in the next section, similar findings were found with regard to institutions' actual practices.

Opinions on the impact of integrating religious beliefs 
The impact of integrating ESG factors into investment decision has been the object of ongoing debate and extensive academic study. Many studies have argued that ESG factors can help investors avoid risks and help them identify high quality corporate management (Camejo, 2002; Derwall et al., 2005; Bauer, 2006; Edmans, 2010), while others have argued that any restriction on a universe of potential investments may increase undiversified risks and reduce risk-adjusted returns (Rudd, 1981; Kreander et al., 2005; Barnett and Salomon, 2006; Bauer, 2006; Renneboog, 2008) ${ }^{8}$. Many authors however tend to indicate that ESG screening does not hurt a fund's financial performance (Statman, 2000; Bauer et al., 2005; Benson et al., 2006; Bauer et al., 2007; Amenc and Le Sourd, 2010). For example, a review of 31 socially screened mutual funds from 1990 to 1998 found that on average they outperformed their unscreened peers, but not by a statistically significant margin (Statman, 2000). Similarly, a 2001 academic review of 80 studies on the links between CSR and financial performance found that 58 percent of the studies observed a positive relationship to performance, 24 percent found no relationship, 19 percent found a mixed relationship, and only 5 percent found a negative relationship (Margolis and Walsh, 2001). Research also provides evidence that RI investors hold very diverse beliefs regarding the financial returns of RI (Lewis and Mackenzie, 2000).

Our survey revealed that the same ambiguity exists among religious institution. Indeed, respondents' opinions on the impact of integrating religious beliefs in investments varied significantly. $69 \%$ of the respondents believed that religious considerations can negatively affect investment returns but, at the same time, over $87 \%$ believed that it can positively affect investment returns.

\section{Practices}

After presenting the opinions of religious organisations on faith and investing, we move to their actual practices. A large majority of them practiced one or another form of RI: $88 \%$ practiced shareholder engagement, $87 \%$ practiced negative screening, $79 \%$ practiced positive screening and $77 \%$ practiced impact investing. These results are not entirely surprising since most of the respondents were members of RIGs whose purpose is to stimulate and encourage RI practices among religious organisations. However the high rate of religious organisations practicing impact investing was unexpected since this activity is more innovative and by far less mainstream. We can therefore assume that our respondents are among the most aware and advanced investors with regard to RI practices. Only two of the respondents used none of the RI approaches. One of them strongly believed that faith should be reflected in investment practices while the other one had no opinion on this issue. However, the two saw all the RI approaches as appropriate practices; they just did not practice them. They both believed that there were not enough financial products to reflect their religious beliefs in their organisations'

\footnotetext{
${ }^{8}$ For those interested in an extensive annotated bibliography of academic studies on this topic, see the web site maintained by the Center for Responsible Business, sristudies.org (www.sristudies.org).
} 
investments. One said that it was not possible to design an investment approach that reflected their religious beliefs. Even if it is not statistically significant, it is interesting to note that the two respondents were the two sole Jewish respondents. It might indicate a lack of financial products that can accommodate Jewish beliefs, or that Jewish investors fail to provide guidance on what financial products should entail.

Table 2 provides an overview of the most common practices (negative and positive screens, engagement and impact investing projects) among the religious organisations that responded to our survey. The next paragraphs detail those practices.

\section{Negative screens}

According to the survey, the negative screens most used by religious organisations are the following: nuclear weapons (70\%), military armaments $(68 \%)$, tobacco $(62 \%)$, pornography $(60 \%)$ and abortion (51\%). Screens such as human rights violations (50\%) and related topics like slave-or child labour ( $44 \%$ and $40 \%$ respectively) were slightly less used. $13 \%$ of respondents did not use any negative screening, which aligned with the response earlier in the survey where $86 \%$ of respondents indicated that they avoid investing in companies whose activities or products were considered inappropriate. It is important to note that the religious organisations not using those negative screens might well be engaging on those issues with the companies via other means such as for example shareholder engagement. Indeed negative screening is only one of the strategies to exert pressures or voice concerns with the companies.

Although it was not part of the survey, these results raise an interesting question with regard to where the criteria for negative screening come from in the case of religious organisations. Through the focus groups we conducted, our exchanges with $3 \mathrm{iG}$ team and some of its members combined with Internet search, we can provide some elements of answer. For the Catholic tradition, negative screening of activities related to arms, tobacco and human rights violations is derived from its "understanding [of] the common good and wellbeing of people and society". The Catholic Missionary Oblates of the Mary Immaculate exclude 7 to $10 \%$ of the US stock listed companies based upon these principles. They emphasised that not only the Holy Scriptures themselves have led them to those screening results, but also "reflections and contemplations" published by the Vatican Catechism and Compendium played an important role in their decision making process (Compendium of the Catechism of the Catholic Church, 2005; Catechism of the Catholic Church, 1993).

One of the Jewish representatives we talked to highlighted the following: "We need to take every reasonable step to make sure that the things we own do no harm", (Rabbi Mordechai Leibling, cited in $3 \mathrm{iG}, 15$ th November 2007). According to him, this can be regarded as the Jewish reasoning for screening. For example, the Jewish religious institution Shoresh Charitable Trust excludes hedge funds based upon the Jewish ban on gambling. Concrete guidelines on negative screening are also found at the Methodist social principles that state: "Trade and investment should be based on rules that support the dignity of the human person, 
a clean environment and our common humanity. Trade agreements must include mechanisms to enforce labour rights and human rights as well as environmental standards" (The Economic Community, 2008).

Our discussions with religious organisations active in responsible investment has also revealed that many of them apply negative screening based on their religious principles but that it is not always straight forward and easy. On the contrary, many of them highlighted the many dilemmas they were facing in the implementation of the criteria and the complex, sometimes stretched link between criteria and faith principles. Pornography may be one of those difficult screens. One may want to distinguish between the making and the selling of pornography. It may be rather easy to exclude companies on the pornography making criteria, but much not so obvious when considering pornography selling which is the case in the hotel industry. The exact percentage of revenues derived from pornography selling is often hard to find and companies are not transparent about it.

Comparing our results with the negative screens used by the secular responsible investment community revealed a variation in interests. According to different studies, the secular RI community has shifted from focusing highly on tobacco and gambling in 2003 (US SIF 2001) to screening on weapons in 2008 (Eurosif, 2008). In 2008, 'norms-based screening' was in the second position; according to this approach the yardstick is companies' compliance with international standards and norms such as those issued by OECD, ILO, UN, UNICEF, etc. It might come as a surprise that religious investors focus less on norms-based screening. On average, they showed less concern about human rights violations, slave labour, and child labour $(45 \%)$ than tobacco (62\%), pornography (60\%), abortion (50\%) and gambling (46\%). Whilst $60 \%$ of the religious investors screen for pornography (\#4 on the list), pornography is less vital for secular responsible investors and it is not found in the top 5 exclusionary screens most commonly used by secular responsible investors (US SIF, 2001).

In short, the secular RI community and religious organisation have a common negative screen, namely the weapon industry. But their priorities are slightly different on other screens: the religious organisations focus more on avoiding certain products and services, whilst the secular RI community focuses on norms-based screening.

Positive screens

When asked what positive criteria religious organisations used (investing in companies that show evidence of corporate social responsibility), environmental policy and programs was the screen mentioned most frequently (by $61 \%$ of the respondents). Employee welfare and rights was the second most important positive screen with more than $50 \%$ of the respondents using it. $21 \%$ of respondents did not use positive screens. These results are not entirely surprising as various Holy Scriptures refer to environment, human welfare and human rights, social justice and good stewardship or as Rev. Dr. Séamus P. Finn puts it "each religious tradition has as horizon of reference the human-divine, the human-human and the human-earth relationships" 
(Finn, 2010). Indeed, already in 1970, Pope Paul VI (1970) had mentioned the ecological problem together with unemployment and discrimination among others as some of the main challenges of post-industrial society (Rossetti, 2005).

When comparing positive screens to the secular RI community, we can notice that environmental concerns are also the most used positive criteria in Europe, while employee issues come third (SRI Compass, 2003). This suggests that there are few differences in positive screening between the secular RI community and religious organisations.

Impact investing

Respondents were asked several questions related to impact investing. A first question was about the type of projects they support through impact investing. Community development (53\%), microfinance (47\%) and affordable housing (42\%) were the most frequently used types of impact investing projects. Perhaps surprisingly religious investors were far less involved in health $(17 \%)$, agriculture $(15 \%)$ or forestry $(7 \%)$ and $23 \%$ did not practice impact investing at all. Some religious organisations have a very broad approach to impact investing. For example the Church of Norway' impact investing policy strongly focuses on enterprises that have microfinance as one of their business areas, and in enterprises whose policy is to promote fair trade or to make direct investment in developing countries (Opplysningsvesenets fond, 2003).

We then asked religious organisations about the return rate of impact investing. More precisely, we asked whether or not they were ready to accept below market rate for this specific type of investment. Whilst six respondents mentioned that impact investing did not give a belowmarket rate return, almost one third of religious investors mentioned that $10 \%$ of their impact investments gave a lower rate of return. Eight respondents accepted a lower rate of return for all their impact investing. Oddly enough, 33\% of respondents did not know what percentage of their organisation's impact investing yielded a lower market rate return. This seems to suggest that, at least for now, many religious organisations do not subject impact investing to the same degree of financial scrutiny as they do with other types of investments.

Finally we asked participants about the value of their assets currently invested in impact investing. The survey mentioned figures in Euros and the exchange value in US Dollars. A big difference in asset allocation was observed in this connection, ranging from $22 \%$ investing less than half a million Euros (less than 0.73 million US\$) to $9 \%$ investing over 50 million Euros (over 73.3 million US\$). In addition, a rather large number of respondents preferred not to disclose the figures $(13 \%)$ or did not know how much their institution invested in impact investing (14\%).

Overall, despite these differences, impact investing was widely practiced amongst religious investors. This is in line with a study of $3 \mathrm{iG}$ in 2010 (3iG, 2010a, b). Religious investors seem to be pioneering this new development in the RI field. 
Shareholder engagement

As suggested already by previous answers to this survey, there seems to be a strong belief among religious investors that they should be active shareholders. Mainly legislative tools and shareholder-management communication were thought to be appropriate. Several respondents indicated that they practiced shareholder engagement via religious investor groups. For example the services of organisations like ICCR in the USA or the German Catholic Bishops' Organisation for Development Cooperation in Europe are used by religious organisations to exercise their shareholder rights. Proxy voting, writing letters and shareholder resolutions filing were used by over $50 \%$ of respondents. $13 \%$ did not engage as shareholders.

Shareholder engagement practices are quite diverse among religious institutions. For examples the General Board of Pension and Health Benefits of The United Methodist Church (GBOPHB) and the Missionary Oblates of the Mary Immaculate (OMI) practice active shareholder engagement (interview with Mrs V. Bullock, Board member of GBOPHB and Rev. S. Finn, Board member of OMI and $3 \mathrm{iG}$ Board). They do it both directly and through a religious investor group. In most of the cases, the GBOPHB proceeds as follow: when an issue comes up, the GBOPHB first writes a letter to the company or companies concerned to ask for clarification on the policies and practices in regards to the issue. If the company does not want to be cooperative, the next step is to meet company's representatives to discuss the issue more in-depth. In case the company does not reply or provides an insufficient response, GBOPHB files a shareholder resolution to formally begin the active shareholding process. This resolution is either filed by GBOPHB directly or through organisations like ICCR for Food and Water sector and Labour standards; Ceres for Environment and Climate related issues; and Social Investment Forum. Finally, if the discussion with the company is not fruitful or if they don't show any response, GBOPHB raises the issue at the company' Annual General Meeting. As for the OMI, resolutions are used only if the issues are not solved through dialogue with the companies. Meetings might be ongoing for 3-4 years before resolutions are made, which is the case with the mining industry for example. The OMI withdraws its resolution if they feel that the discussions with the management are developing positively.

According to the Eurosif 2008 annual survey, proxy voting is also the most common form of engagement among the secular RI community (over 40\%), followed by direct private engagement (including writing letters and holding meetings with company representatives) (Eurosif, 2008). However, comparing the Eurosif study with our survey, direct engagement and filing shareholder resolutions would be significantly less used by the secular RI community (10 to $15 \%)$ than by religious organisations (56\% and 50\%).

Once again those results have to be understood in light of our sample which is dominantly based in North America. As other studies have shown, North America especially the USA has a longer history of shareholder activism and is more inclined to engage as shareholders (Louche and Lydenberg, 2006). 
Table 2 - The most common screens, engagement practices, and impact investing areas used by religious organisations

\begin{tabular}{|c|c|c|c|}
\hline Negative screens & Positive screens & Engagement & Impact investing \\
\hline $\begin{array}{l}\text { 1. Nuclear weapons } \\
\text { 2. Military } \\
\text { armaments } \\
\text { 3. Tobacco } \\
\text { 4. Pornography } \\
\text { 5. Abortion }\end{array}$ & 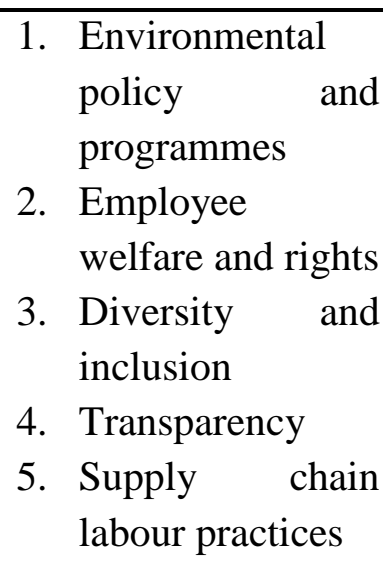 & $\begin{array}{l}\text { 1. Proxy Voting } \\
\text { 2. Writing letters } \\
\text { 3. Shareholder } \\
\text { resolutions filing } \\
\text { 4. Having meetings } \\
\text { with company's } \\
\text { representatives } \\
\text { 5. Divesting }\end{array}$ & $\begin{array}{ll}\text { 1. } & \begin{array}{l}\text { Community } \\
\text { development }\end{array} \\
\text { 2. Micro-finance } \\
\text { 3. Affordable } \\
\text { housing } \\
\text { 4. Fair trade } \\
\text { 5. Clean energy or } \\
\text { environmental } \\
\text { management }\end{array}$ \\
\hline
\end{tabular}

Research process

Practicing FCI requires religious organisations not only to develop criteria and policies but also to collect information about companies' activities, practices, and behaviour.

Through our interviews and focus groups, we found two important characteristics with regard to the research process. First the religious organisation representatives we have talked to were in general very reticent in using company's public reports. They favour other independent sources. For example important and decisive sources of information for the Jewish Shoresh Charitable Trust are "reputable" newspapers and information given by asset managers.

Second, similarly to the secular responsible investment community, some religious organisations use the services of social rating agencies such as for example KLD, Sustainalytics, Riskmetrics, ISS, EIRIS and others. For example, the Methodists Board of Pensions and Mary Oblates in the USA use the screenings from KLD. However independent rating organisations are mainly used by large religious organisations. Religious organisations with a smaller investment portfolio tend to use other sources such as the media information.

In general, the research process used by religious organisation remains rather obscure. Religious organisations' website do not provide extended information on their methodology and methods for screening companies. Even the methodology used for the STOXX Europe Christian Index provides little information.

\section{Barriers/Facilitators}


The survey clearly pointed out that in general respondents tended to reflect their beliefs in their investment practises. However, to what extent is this possible? Are there any barriers or facilitators to practicing faith consistent investing? We are going to explore these questions with a special focus on the barriers in this part of our analysis.

Religious organisations were enquired whether religious beliefs were reflected in investment approaches on a scale from 1 to 7 , where 1 meant that their religious beliefs were not reflected at all in their investment approach, while 7 meant a high connection between the two. The average response was high, 5.46, which is rather high. And almost all of them agreed that it was possible to design an investment strategy that aligned with their religious principles (only $7 \%$ disagreed on this statement). Yet, when entering more into details, religious organisations mentioned that they encountered various obstacles in trying to put faith consistent investing into practice. They would actually be inclined to invest more according to their faith beliefs if certain tools and services were available to them. $37 \%$ of the respondents felt that changing existing investment practices of the mainstream investment community is something difficult. However integrating religious principles or CSR dimensions requires changes and adjustments (Louche \& Lydenberg, 2011). The investment community is engrained in a strong and dominant logic which may be highly resistant to change. If religious organisations wish to add criteria or innovate in terms of investment strategy, to better align their principles of faith to their investment practices, it may well be difficult to get heard by the financial community and even more difficult to get religious organisations' requirements or demands implemented. However, when responding to the question on their power of influence with regard to investment strategy, only a small minority (8\%) believed they could not exert any influence. Our results showed a small contradiction that would be worthwhile to explore further. On the one hand religious organisations felt it is difficult to change existing practices, but on the other hand they felt they did have certain power on investment decisions. Note that $50 \%$ of the respondents followed the advice of their financial advisor. This highlights the potential key role of financial advisors in the investment process of religious organisations but also in changing mainstream finance.

To better understand the obstacles and impediments for changing existing investment practices, the participants had to react to several statements. In general, there seemed to be a great need for a less complex investment market with tools and services more appropriate for religious investment purposes. $29 \%$ of respondents felt that investing was so complicated that it was difficult to comprehend all the products and tools that were offered and $26 \%$ mentioned that there was a lack of financial products enabling their organisations to reflect their religious beliefs in their investments. Indeed, 2 respondents said that it was not possible to design an investment approach that reflected their religious beliefs.

In the survey, we also asked religious organisations what support was needed to make investments more faith-consistent. 50\% of the respondents mentioned they would significantly increase their investments (assuming they had the necessary financial resources) if their investment manager were able to offer an option for aligning investments with their religious 
beliefs. Furthermore, $51 \%$ said they would be inclined to invest more if there were reliable tools for developing and maintaining an investment fund that reflected their religious beliefs.

When asked what evidences were required to increase investments in a faith consistent way, several religious organisations focused more on evidence of a positive impact on society and on company behaviour rather than on avoiding the risk of poor financial performance.

Overall, there seem to be some difficulties in putting religious beliefs into investment practice. Religious organisations cannot implement faith consistent investing alone; they depend on the offerings of financial institutions. The current investment market is not fully equipped or willing to provide tools and services that are required by religious organisations. Religious organisations also require a less complex investment market. Customised religious investment products could attain this. Customisation and simplification would attract more religious money into the global responsible investment market. However religious organisations are not a homogenous group. They represent many religions with each its own and different requirements that can probably not be translated in one single tool but rather requires a variety of approaches.

\section{Regional differences}

Whilst no significant differences were noticed in the opinions of US versus non-US respondents, the practices differed between the two groups. Our sample consisted of $61 \%$ religious organisations based in the United States of America and 39\% from elsewhere around the world.

When looking at differences in practices, some topics should be highlighted. The first focus was on negative screening. US religious investors placed greater emphasis on abortion (60\% USA versus $41 \%$ non-USA), while pornography was a more important exclusionary screen among the non-US respondents than among US respondents (54\% USA versus $67 \%$ non-USA) (see Table 3).

Table 3 - Tope 5 negative screening practices USA/ versus non-USA

\begin{tabular}{ll}
\hline USA & Non-USA \\
\hline 1. Nuclear Weapons & 1. Pornography \\
2. Military armaments & 2. Military armaments \\
3. Tobacco & 3. Nuclear weapons \\
4. Abortion & 4. Tobacco \\
5. Pornography & 5. Abortion \\
\hline
\end{tabular}

When looking at the usage of positive screens, US-based religious investors were more 
interested in diversity and inclusion than non-US investors (58\% versus $39 \%$ ) but were less concerned with transparency than non-US religious investors (31\% versus $48 \%$ ) (see Table 4 ). Furthermore, US respondents generally showed more interest in positive screening than did non- US ones.

Table 4 - Tope 4 positive screening practices USA versus non-USA

\begin{tabular}{ll}
\hline USA & Non-USA \\
\hline 1. Diversity and inclusion & 1. Employee welfare \& rights \\
2. Employee welfare \& rights & 2. Transparency \\
3. Supply chain labour practices & 3. Diversity and inclusion \\
4. Transparency & 4. Supply chain labour practices \\
\hline
\end{tabular}

When it comes to impact investing, the differences between US-based religious investors and non-US religious investors were sharper. More than double the USA-based respondents practiced community development (71\% in the USA versus $33 \%$ non- USA) and affordable housing (60\% versus $22 \%)$ than non- US, whilst non-US respondents formed the majority of investors in clean energy or environmental management (see table 5).

Table 5 - Tope 4 impact investing activities USA versus non-USA

\begin{tabular}{ll}
\hline USA & Non-USA \\
\hline 1. Community development & 1. Clean energy \& Environmental \\
2. Microfinance & management \\
3. Affordable housing & 2. Micro finance \\
4. Fair trade & 3. Community development \\
& 4. Affordable housing
\end{tabular}

The value of religious organisations' asset allocation to impact investing varied widely. Some respondents did not know; this went for 7 out of 43 US-based investors and 3 out of 26 nonUS based investors. Nine US-based respondents indicated they did not disclose information on impact investing asset allocation. Although the opinions of religious organisations towards investment practices in the USA and outside the USA did not differ significant, there were interesting regional differences in practices. 


\section{Conclusion and Discussion}

The aim of this paper was to study faith consistent investing. In this process, we investigated religious organisations' attitudes towards responsible investing. We more especially explored religious organisations' opinion about investing, their investment practices, and the potential impediments for matching faith beliefs and investing.

To examine those questions, we conducted a survey among religious organisations. Given the growing interest in responsible investment, the fact that religious organisations are possibly, when taken together, the third largest group of investors in the world but also the exemplary, educational and advisory role these organisations play for their members, this survey contributes in shedding light on a research field of a major importance. In light of the results of the survey, six main findings are presented. Thereafter we provide some potential directions for further research.

\section{Main findings}

Faith consistent investing is possible. Religious organisations do not see any contradiction between the activity of investing and religion. Investing is a fully accepted activity as long as it is done respecting faith beliefs. The faith dimension is a factor that increases the religious organisations' sensitivity and awareness towards the non-financial impact of their investment activities. The research also highlights a certain alignment between religious organisations' beliefs and actions. The responses show that faith consistent investing is highly practiced. Nonetheless we ought to put the results into perspective, as our sample is not fully representative of the religious organisations community and biased towards organisations that are already active in FCI.

Beyond financials. Our results highlight the fact that religious organisations go beyond the financial aspects of investing. They seem to be highly driven by the impact they can have on companies' behaviour or society and therefore do not limit the purpose of investing to purely financial returns. As noted by Rev. Dr. Séamus P. Finn in his oration to the Ninth Harvard University Forum on Islamic Finance (March 27 ${ }^{\text {th }}, 2010$ ): "Faith traditions provide both the principles and the moral compass to evaluate a financial system in terms of its contribution to the well-being and future of both people and planet" (Finn, 2010). Although important, the market-rate returns did not come out as a determining factor to increase their investments but rather as a minimum requirement. However the tensions between the finances and the principles seem to remain a critical debate and to pose dilemmas for religious organisations, as much as within the financial community where there is not yet a clear answer.

Religious Investor Identity. An interesting characteristic of FCI is that religious investors have set up their own specific networks where only (or dominantly) religious organisations are members. Although a few of them have joined secular RI networks, such as the UNPRI, most of the religious organisations limit their membership to FCI networks. Is it for historical 
reasons? Is it related to divergent views on RI? Is it a search or a need to strengthen an 'identity'? Our results do not allow us to give a full explanation. However, we can hypothesise some elements for an answer. There are probably organisational reasons related to the way religious organisations operate and are structured. There are most probably reasons related to some principles which may be felt as stronger and sharper among religious organisations. Cultural reasons can also play a role as religious organisations may share a vocabulary, worldview and ways of working, which distinguishes them from secular RI actors. But maybe more importantly religious organisations can be regarded as collective of multiple organisations or individuals who are conscious of forming a group (Rowley and Moldoveanu, 2003) and with a collective identity that articulates their shared interests and goals (Klandermans, 1984). Certainly more research is necessary to find out why there are not only different but also separate networks for FCI and secular RI.

Yet, whilst religious organisations have created their own networks, it seems that the practice of RI does not differ significantly from those of the secular RI community, for example in terms of the negative screens used or the engagement practices. The reason for this might be the absence of specific religious-based financial tools and services compared to the availability of secular RI products. Another potential reason, and an interesting line for further research, is that the secular RI community is more religiously inspired than it might realise.

Impact Investing Revitalised. Impact investing has been practiced by religious organisations for a very long time. Indeed impact investing may be an investment activity that best fits religious organisations' principles and objectives. The interest of religious organisations for impact investing comes from the fact that they have a slight preference for investing in projects or companies that do a clear a direct social good, rather than adopting "best in class approaches" (i.e. they 'choose the best within the limitations of capitalism'). Therefore impact investing comes as an activity with fewer ideological tensions than other FCI practices.

This is quite well illustrated by the vision of the Jewish values-based investment guide: "Money is not merely a means to increasing wealth, but can itself be a way to advance important social goals. In Jewish tradition, the highest form of charity is to make a business partnership with a potentially needy person; conversely, investments that patently promote antisocial activities are prohibited" (Meir, 2009). However, in the past impact investing was never defined as a responsible investment activity. It is only recently that it has been slightly reshaped and redefined to enter the field of responsible investment. On the one hand, it is being revitalised among religious institutions, and on the other hand it is emerging as an interesting field among mainstream financial institutions. One may ask whether, once again, religious organisations are pioneering a new development in this area of investment. This leads to the question of whether religious organisations can foster change in the financial system or play the role of 'norm entrepreneurs'. Norm entrepreneurs are actors who seek to actively persuade other actors that a new norm is superior to the existing standard of appropriateness (Sjöström, 2010). 
Beliefs versus Practices. Practicing FCI does not come out as an easy and straightforward activity. Indeed our research points at some impediments. Religious organisations cannot implement faith consistent investing alone; they depend on the offerings of financial institutions. If the investment market does not provide tools and services integrating the needs and requirements of religious organisations, it makes it difficult or almost impossible to fully practice FCI. Our research also highlighted that religious organisations do not always managed their investment by themselves alone, but do it in collaboration with a financial manager. Another hurdle is then to convince the financial manager to apply and respect the religious principles in the investment activity. Whether financial managers have the right incentives and the adequate skills to do so remains an open question. Our research also showed that religious organisations often find investment products too complex and therefore difficult to fully comprehend and maybe to control.

Because of different principles of faith, customisation is another issue which could facilitate FCI and attract religious organisations to practice it. This leads to another debate, outside the scope of this paper, about common and diverging principles among the different religions. Some argue that there are 'root differences' between religions (Fehrenbacher, 2001) and others claim that there is a greater commonality of religious values as opposed to other types of values, for example, national values (Inglehart and Baker, 2000). Moreover it remains crucial to raise the question of whether all religious principles are applicable and should be implemented in investment activities. Our research already triggered questions on controversial consequences of integrating faith beliefs in investing. For example certain religious funds screen out companies on behalf of their religious principles like Wyeth for manufacturing birth control pills, Merck \& Company for foetal tissue research, Procter \& Gamble for donating to Planned Parenthood and Amazon.com for officially recognising gay and lesbian groups. It raises the questions of the universality of the principles and the purpose or the objectives of using certain screens. Those questions are certainly not limited to FCI but might be more pressing with regard to specific criteria like the ones mentioned above.

Regional Differences. Although there are no major differences between religious organisations in the USA and outside the USA, some variations are worth mentioning. When excluding products and services, USA religious investors placed more emphasis on abortion than non-US religious investors, whilst pornography was screened more by non-US religious investors. Of the positive screens, diversity and inclusion was relatively more important in the USA whilst non-US religious investors focused more on transparency than USA ones. Evidence on impact investing research showed a significant higher interest in community development and affordable housing by the USA investors. Finally US religious investors practiced impact investing more than their religious co-investors outside the USA do. Again more research is needed on regional differences as well as on intra and inter-religion. The characteristics of our sample limited our capacity to carry a comparative analysis. 


\section{Directions for further research}

This study provides important insights into faith consistent investing. Despite having historically pioneered many RI initiatives, little is known on religious institutions' beliefs and practices towards investing today and FCI. This survey is a major contribution to this underresearched field. It can serve as a basis for further research, as we highlight in the following.

Our study highlights regional differences between US and non-US religious organisations. However the scope of our sample did not allow us to fully investigate those differences and especially did not allow going more into details into the different regions. But we have strong indications that religious organisations do not have the same FCI practices in the different regions of the world. It would be valuable to study more in-depth those geographical differences around the world. There are also inter- and intra-religious differences that are worth studying. Although it was not the objective of our survey to study intra-religious differences, our discussions with religious organisations revealed that within a same religious group views differ. For example the creation of the STOXX Europe Christian Index in 2010 was an intense and sometimes difficult process to come up to an agreement on the criteria that should be applied.

The survey provides an overview of the religious organisations FCI practices but many questions remain and further research is required to better understand those practices. We would especially make a call for more research on two specific activities, namely impact investing and shareholder engagement. More fine-grained research is needed on how they are practiced, the drivers for practicing those activities but also in terms of the impact they have.

The relationship between religious values and investment strategy needs be better understood. Obviously the religious organisations of our sample and the ones we talked to tried to link their investment practices with their religious principles. But the link is not always obvious and the articulation values and investment practices remains relatively unsophisticated and vague. For example, one could ask what exact religious conviction determines the exclusion of tobacco. Moreover, a variety of other factors, next to religious values, most probably impact investment strategies and affect the influence of those values. A more qualitative research based on interview and discourse analysis could help to better understand and characterise this relation.

The decision making process with regard to investment policy but also to the final investment decisions remain a black box. Little is known about who sets the investment policy and who has the decision power within religious organisations. A previous study (Ross, 2005) showed that financial issues remain a topic of 'fear' among religious actors and for an important part delegated to external professional advisers. The importance of the external advisers is also something we noticed in our survey. This black box needs to be open to better understand the decision making process with regard to FCI and the factors that influence those decisions. 
Finally the paper raises the issue of identity for FCI and the FCI network. As highlighted in the results, religious organisations have their own networks and don't seem to mix with the RI community. A promising line of research would be to use social movement theory, as it has been suggested by Arjalies (Arjalies, 2010), to explore the group dynamics of religious organisations practicing FCI and how they are affecting and are affected (or not) by the broader responsible investment community. 


\section{References}

3iG: 2010a, 'To contribute to a just and sustainable society through responsible investment in a spirit of genuine interfaith dialogue and co-operation', International Interface Investment Group (3iG), Retrieved 11 August 2011 from http://www.3ignet.org/resourcecenter/documents/3iGleafletelectronicversion.pdf.

3iG: 2010b, Faith Institutions and Impact Investing: An Introduction, International Interfaith Investmet Group (3iG), Retrieved April 5, 2011 from http://www.3ignet.org/resourcecenter/resourcePDFs/3iG_impact_investing_April_2010 .pdf.

Acquier, A., J.-P. Gond and J. Igalens : 2005, 'Des fondements religieux de la responsabilité sociale de l'entreprise à la responsabilité sociale de l'entreprise comme religion', Cahiers du Centre de Recherche en Gestion, Université de Toulouse, $\mathrm{N}^{\circ} 166$.

Al-Amine, M. and M. Al-Bashir: 2001, 'The Islamic Bonds Market: Possibilities and Challenges', International Journal of Islamic Financial Services, 3(1): 1-18.

Amaeshi, K.: 2010, 'Different Markets for Different Folks: Exploring the Challenges of Mainstreaming Responsible Investment Practices', Journal of Business Ethics, 92,41-56.

Amaeshi, K. and D. Grayson: 2006, 'The Challenges of mainstreaming Environmental, Social and Governance (ESG) issues in Investment Decisions: A mini-survey of practitioners' reports'. Working paper, Cranfield School of Management, SDA Bocconi and Vlerick Leuven Gent Business School.

Amenc, N. and V. Le Sourd: 2010, 'The Performance of Socially Responsible Investment and Sustainable Development in France: An Update after the Financial Crisis', EDHECRisk September, Retrieved October 29, 2010 from http://docs.edhecrisk.com/mrk/000000/Press/EDHEC-Risk_Position_Paper_SRI.pdf.

Anand, P. and C. J. Cowton: 1993, 'The ethical investor: Exploring dimensions of investment behaviour', Journal of Economic Psychology, 14, 377-385.

Archer, S. and R. A. Karim: 2002, Islamic Finance, Innovation and Growth. London, (Euromoney books and AAOIFI).

Arjaliès, D.: 2010, 'A Social Movement Perspective on Finance: How Socially Responsible Investment Mattered', Journal of Business Ethics, 92, 57-78. 
Barnett, M. L. and R. M. Salomon: 2006, 'Beyond dichotomy: the curvilinear relationship between social responsibility and financial performance', Strategic Management Journal, 27(11), 1101-1122.

Bauer, R., J. Derwall, and R. Otten: 2007, 'The Ethical Mutual Fund Performance Debate: New Evidence from Canada', Journal of Business Ethics, 70 (2), 111-124.

Bauer, R., N. Guenster, J. Derwall and K. Koedijk: 2006, 'The Economic Value of Corporate Eco-Efficiency', Available at SSRN: <http://ssrn.com/abstract=675628>, Accessed on 29 October 2010.

Bauer, R., K. Koedijk, R. Otten: 2005, 'International evidence on ethical mutual fund performance and investment style', Journal of Banking \& Finance, 29(7), 1751-1767.

Bauer, R., R. Otten and A. Tourani Rad: 2006, 'Ethical investing in Australia: Is there a financial penalty?', Pacific-Basin Finance Journal, 14(1), 33-48.

Benson, K., T. Brailsford, and J. Humphrey : 2006, 'Do Socially Responsible Fund Managers Really Invest Differently?', Journal of Business Ethics, 65(4), 337-357.

Benedict XIV: 1745, 'Vix Pervenit: On usury and other dishonest profit', http://www.papalencyclicals.net/Ben14/b14vixpe.htm, Accessed August 9, 2011.

Best, S. J. and B. S. Krueger: 2004, Internet Data Collection (SAGE Publications, Inc).

Booth, P.: 1993, 'Accounting in Churches: A Research Framework and Agenda', Accounting, Auditing \& Accountability Journal, 6(4): 37-67.

Brammer, S., G. Williams, and J. Zinkin: 2007, 'Religion and Attitudes to Corporate Social Responsibility in a Large Cross-Country Sample', Journal of Business Ethics, 71(3): 229243.

Breckler, S. J.: 1984, 'Empirical Validation of Affect, Behavior, and Cognition as Distinct Components of Attitude', Journal of Personality and Social Psychology, 47, 1191-1205.

Bugg-Levine, A. and J. Goldstein: 2009, 'Impact Investing: Harnessing Capital Markets to Solve Problems at Scale', Community Development Investment Review, San Francisco, CA, Federal Reserve Bank of San Francisco, 5(2), 30-41.

Camejo, P.: 2002, The SRI advantage: Why socially responsible investing has outperformed financially, (Gabriealla Island, British Columbia, New Society Publishers).

Catechism of the Catholic Church: 1993, 'Libreria Editrice Vaticana, Citta del Vaticano', http://www.vatican.va/archive/ENG0015/_INDEX.HTM, Accessed on 02 August 2011. 
Clark, G. L. and T. Hebb: 2004, 'Pension Fund Corporate Engagement', Industrial Relations, 59(1), 142-171.

Clark G.L., Salo J. and Hebb T.: 2008, 'Social and Environmental Shareholder Activism in the Public Spotlight: US Corporate Annual Meetings, Campaign Strategies, and Environmental Performance, 2001-04', Environment and Planning, 40(6), 1370-90.

Cohen, R.: 2010, 'Israel and the Holy See Negotiate: A Case Study in Diplomacy across Religions', The Hague Journal of Diplomacy; 5(3), 213-234.

Compendium of the Catechism of the Catholic Church: 2005, 'Libreria Editrice Vatican' http://www.vatican.va/archive/compendium_ccc/documents/archive_2005_compendiu m-ccc_en.html, Accessed on 02 August 2011.

Cordes, R.: 2010, "Impact Investing', Financial Planning, 40(5), 45-48.

Cowton, C.: 1994, The development of ethical investment products. In A.R. Prindl\& B. Prodhan (Eds.), Ethical conflicts in finance (pp.213-232). Oxford: Blackwell.

Cowton, C.: 1998, Socially responsible investment. In R. Chadwick (Ed), Encyclopaedia of applied ethics. San Diego: Academic Press.

Crites S.L., L.R. Fabrigar and R.E. Petty: 1994, 'Measuring the Affective and Cognitive Properties of Attitudes: Conceptual and Methodological Issues', Personality and Social Psychology Bulletin, 20(6), 619-634.

Déjean, F., J.-P. Gond, and B. Leca, 2004 'Measuring the Unmeasured: An Institutional Entrepreneur's Strategy in an Emerging Industry’, Human Relations, 57(6), 741-764.

Delorenzo, T. Y.: 2002, 'The Religious Foundations of Islamic Finance' in S. Archer and R. A. Karim (eds), Islamic Finance, Innovation and Growth (London, Euromoney books and AAOIFI).

Derwall, J., N. Guenster, R. Bauer and K. Koedijk: 2005, 'The Eco-Efficiency Premium Puzzle', Financial Analysts Journal, 61(2), 51-63.

Diltz, J. D.: 1995, 'Does Social Screening Affect Portfolio Performance?', Journal of Investing, Spring, 64-69.

Domini, A. L.: 2001, Socially responsible investing : making a difference in making money, (Chicago, Dearborn Trade). 
Duncan, J. B., D. L. Flesher, and Stocks M.H.: 1999,. 'Internal control systems in US churches: An examination of the effects of church size and denomination on systems of internal control', Accounting, Auditing \& Accountability Journal, 12(2), 142-163.

Durkheim, E. : 2003, Les Formes élémentaires de la vie religieuse, (Presses Universitaires de France, 5eme edition, Paris).

Edmans, A.: 2010, 'Does the Stock Market Fully Value Intangibles? Employee Satisfaction and Equity Prices', Available at SSRN: 〈http://ssrn.com/abstract=985735>, Accessed on 29 October 2010.

Eurosif: 2008, 'European SRI study', Available at: http://www.eurosif.org/publications/sri_studies. Accessed on 29 October 2010.

Eurosif: 2010, 'European SRI Study 2010', Eurosif. Paris, www.eurosif.org/research/eurosifsri-study/european-sri-study-2010 <http://www.eurosif.org/research/eurosif-sristudy/european-sri-study-2010, Accessed on 15 October 2010.

Eurosif. (2010). European SRI Study 2010. Eurosif. Paris: www.eurosif.org/research/eurosifsri-study/european-sri-study-2010 <http://www.eurosif.org/research/eurosif-sristudy/european-sri-study-2010, accessed on 15 October 2010.

Fehrenbacher, S.: 2001, Put Your Money Where Your Morals Are. A guide to Values-based Investing, (Nashville: Broadman \& Holman).

Fishbein, M., and I. Ajzen: 1975, Belief, attitude, intention, and behavior.MA, (AddisonWesley).

Forte, G. M., Miglietta F.: 2007, 'Islamic Mutual Funds as Faith-Based Funds in a Socially Responsible Context', Social Science Research Network.: Available at SSRN: http://ssrn.com/abstract=1012813. Accessed on 11 Augustus 2011.

Ghoul, W. and P. Karam: 2007, 'MRI and SRI Mutual Funds: A Comparison of Christian, Islamic (Morally Responsible Investing), and Socially Responsible Investing (SRI) Mutual Funds', Journal of Investing, 16(2), 96-102.

Girard, E. and M. K. Hassan: 2008, 'Is There a Cost to Faith-Based Investing: Evidence from FTSE Islamic Indices', Journal of Investing, 17(4), 112-121.

Glac, K.: 2008, Explaining socially responsible investing: a framing perspective of the investment decision process, (University of Pennsylvania Press, Minnesota).

Glac, K.: 2009, 'Understanding Socially Responsible Investing: The Effect of Decision Frames and Trade-off Options', Journal of Business Ethics, 87(Supplement 1), 41-55. 
Gordon Pole, D.: 2005, 'Liability of Religious Charities: A New Frontier: Accountability of Religious Persons and Institutions in Tort', The Philanthropist, 20(2), 87-130.

Graaf, d., F. Jan, and A. Slager: 2009, 'Guidelines for Integrating Socially Responsible Investment in the Investment Process', Journal of Investing, 18(3), 70-78.

Graves, S. B., K. Rehbein, and S. Waddock :: 2001, 'Fad and Fashion in Shareholder Activism: The Landscape of Shareholder Resolutions 1988-1998', Business and Society Review, 106(4), 293-314.

Green B.F.: 1953, 'Attitude Measurement', in L. Gardner (eds.), Handbook of Social, Psychology, Vol. 1. (Addison-Wesley), pp. 335.

Guyatt, D. J.: 2005, 'Finance and accounting: Meeting objectives and resisting conventions. A focus on institutional investors and long-term responsible investing', Journal of Corporate Governance, 5(3), 139-150.

Guyatt, D. J.: 2006, 'Identifying and Overcoming Behavioural Impediments to Long Term Responsible Investments - a Focus on UK Institutional Investors', Unpublished doctoral dissertation, Department of Psychology, University of Bath.

Hoffman, A.: 1996, 'A strategic response to investor activism', Sloan Management Review, 37(2), 51-64.

Hood, M., J. Nofsinger, and A. Varma: 2009, 'Sin Stocks and the Religious Investor', Washington State University working paper.

Hui, L. T.: 2008, 'Combining faith and CSR: a paradigm of corporate sustainability', International Journal of Social Economics, 35(6), 449-465.

Inglehart, R. and W. Baker: 2000, 'Modernization, Cultural Change, And The Persistence Of Traditional Values', American Sociological Review, 65, 19-51.

Juravle, C. and A. Lewis: 2008, 'Identifying impediments to SRI in Europe: a review of the practitioner and academic literature', Business Ethics: A European Review, 17(3), 285310.

Katz D.: 1960, 'The Functional Approach to the Study of Attitudes', Public Opinion Quarterly, 24, 163-204.

Keller, C. and M. Siegrist: 2006, 'Money Attitude Typology and Stock Investment', Journal of Behavioral Finance, 7(2), 88-96. 
Kettell, B.: 2008, Introduction to Islamic Banking and Finance, (London, Islamic Banking Training).

Kinder, P. D. and A. L. Domini: 1997, 'Social screening: paradigms old and new', The Journal of Investing, Winter, 12-19.

Klandermans, B.: 1984, 'Mobilization and participation: social-psychological expansions of resource mobilization theory', American Sociological Review, 24(5), 583-600.

Kreander, N., K. McPhail, and Molyneaux D. : 2004, 'God's fund managers: A critical study of stock market investment practices of the Church of England and UK Methodists' Accounting, Auditing \& Accountability Journal, 17(3), 408-441.

Kreander, N., R. H. Gray, D.M. Power, C.D. Sinclair: 2005, 'Evaluating the Performance of Ethical and Non-ethical Funds: A Matched Pair Analysis', Journal of Business Finance \& Accounting, 32(7/8), 1465-1493.

Lewis, A.: 2001, 'A Focus Group Study of the Motivation to Invest: "Ethical/Green" and “Ordinary” Investors Compared', Journal of Socio-Economics, 30(4), 331-42.

Lewis, A. and C. Mackenzie: 2000, 'Morals, money, ethical investing and economic psychology', Human Relations, 53(2), 179-191.

Lewis, A., and C. Mackenzie: 2000. "Morals, money, ethical investing and economic psychology', Human Relations, 53(2), 179-191.

Louche C. and S. Lydenberg :2011, Dilemmas in responsible investment, (Greenleaf Publishing, London).

Louche, C.: 2004, 'Ethical Investment: processes and mechanisms of institutionalisation in the Netherlands, 1990-2002'. Unpublished doctoral dissertation, Erasmus University Rotterdam. Rotterdam.

Louche, C. and S. Lydenberg: 2006, 'Socially responsible investment: difference between Europe and United States', Working Papers, Vlerick Leuven Gent Management School, series 2006-22.

Louche, C. and S. Lydenberg: 2010, 'Responsible Investment', in J. R. Boatright (eds), Finance Ethics: Critical Issues in Financial Theory and Practice, (Wiley, New York), pp 393-418.

Louche, C. and S. Lydenberg: 2011, Dilemmas in Responsible Investment, (Greenleaf Publishing, London). 
Mackenzie, C.: 1997, 'Ethical Investment and the Challenge of Corporate Reform - A critical assessment of the procedures and purposes of UK ethical unit trusts', Unpublished doctoral dissertation, University of Bath.

Margolis, J. D. and J. P. Walsh: 2001, People and Profits? The search for a link between a company's social and financial performance, (Mahwah, NJ: Lawrence, Erlbaum and Associates).

Meir, A.: 2009, 'Jewish values based investment guide for charities and communal organizations', Business Ethics Center of Jerusalem Publication, Available at: http://www.3ignet.org/resourcecenter/documents/JewishCommunalInvestmentGuidelin esNov4th2009.pdf, Accessed on 11 Augustus 2011.

Naughton, S. and T. Naughton: 2000, 'Religion, Ethics and Stock Trading: The Case of an Islamic Equities Market', Journal of Business Ethics, 23(2), 145-159.

Nilsson, J., A.-C. Nordvall, and S. Isberg : 2010, 'The information search process of socially responsible investors', Journal of Financial Services Marketing, 15(1), 5-18.

O’Donohoe, N., C. Leijonhufvud, and Y. Saltuk.: 2010, 'Impact Investments: An emerging asset class', J.P.Morgan. November 19.

Opplysningsvesenets fond: 2003, 'Guidelines for opplysningsvesenets fond's socially responsible investments', Avaialbe at; http://www.3ignet.org/resourcecenter/resourcePDFs/OVF_EthicalGuidelines_hefte.pdf, Accessed on 02 August 2011.

Ostrom, T. M.: 1969, 'The relationship between the affective, behavioral, and cognitive components of attitude', Journal of Experimental Social Psychology, 5, 12-30.

Ramasamy, B., M. Yeung, and A. Au: 2010, 'Consumer Support for Corporate Social Responsibility (CSR): The Role of Religion and Values', Journal of Business Ethics, 91, $61-72$.

Renneboog, L., ter Horst J. and Zhang C.: 2008, 'Socially Responsible Investments: Institutional Aspects, Performance, and Investor Behaviour', Journal of Banking \& Finance, 32(9), 1723-1742.

Rhodes, M.: 2010, 'Information Asymmetry and Socially Responsible Investment', Journal of Business Ethics, 95(1), 145-150.

Rodrigo, P. and D. Arenas: 2008, 'Do Employees Care About CSR Programs? A Typology of Employees According to their Attitudes', Journal of Business Ethics, 83, 265-283. 
Ross, S.A. : 2005, 'Socially Responsible Investment in UK Faith-Based Charities Investigating the impact of religious values on investment strategy', Unpublished MSc Dissertation, Centre for Charity Effectiveness, Cass Business School, City University.

Rossetti A.: 2005, Highlights of Catholic Social Doctrine in relation to Faith Consistent Investing (FCI), Libreria Editrice Vaticana, Vatican City. Availalbel at: http://www.3ignet.org/pdfs/ROSSETTI.pdf, Accessed on 02 August 2011.

Rowley, T. I. and M. Moldoveanu: 2003, 'When will stakeholder groups act? An interest and identity-based model of stakeholder group mobilization', Academy of Management Review, 28(2), 204-219.

Rudd, A.: 1981, 'Social Responsibility and Portfolio Performance' California Management Review, 23(4), 55-61.

Sandberg, J., C. Juravle, T. Hedesström and I. Hamilton: 2009, 'The Heterogeneity of Socially Responsible Investment', Journal of Business Ethics, 87(4), 519-533.

Schaefer, H.: 2004,.'Ethical investment of German non-profit organizations- conceptual outline and empirical results', Business Ethics: A European Review, 13(4), 269-287.

Schwartz, M. S.: 2003, 'The "ethics" of ethical investing', Journal of Business Ethics, 43(3), 195.

Schwartz, M. S., M. Tamari, and D. Schwab: 2007, 'Ethical Investing from a Jewish Perspective', Business \& Society Review, 12(1), 137-161.

Finn, S.P.: 2010, 'Faith and Finance: a catholic consideration', Ninth Harvard University Forum on Islamic Finance. March $27^{\text {th }}$.

Sjöström, E.: 2010, 'Shareholders as Norm Entrepreneurs for Corporate Social Responsibility', Journal of Business Ethics, 94(2), 177-191.

Sparkes, R. (1995). The ethical investor. London, Harper Collins.

Sparkes, R.: 2001, 'Ethical investment: whose ethics, which investment?', Business Ethics: A European Review, 10(3,: 194-205.

Sparkes, R. and C. J. Cowton: 2004, 'The maturing of socially responsible investment: a review of the developing link with corporate social responsibility', Journal of Business Ethics, 52(1), 45-57.

SRI Compass: 2003, ‘Screening policies for SRI funds', Avanzi SRI Research/SiRi Group. 
Stark R. and Bainbridge, W.S.: 1987, A Theory of Religion, (New York, Peter Lang).

Statman, M.: 2000, 'Socially responsible mutual funds', Financial Analysts Journal, 56(3), 30-39.

Statman, M.: 2005, 'The Religions of Social Responsibility', Journal of Investing, 14, 14-22.

The Economic Community: 2008, 'The United Methodist Publishing House'. http://www.umcgbcs.org/site/c.frLJK2PKLqF/b.3713153/k.FC2F/182163_IV_The_Economic_Commu nity/apps/nl/newsletter.asp, Accessed on 02 August 2011.

US SIF: 1999, '1999 Trends Report: Report on Responsible Investing Trends in the U.S.', Social Investment Forum US.

US SIF: 2001, '2001 Report on Socially Responsible Investing - Trend in the United States', Social Investment Forum US.

US SIF : 2010, '2010 Report on Socially Responsible Investing Trends in the United States', US Social Investment Forum. Washington: http://www.socialinvest.org/resources/pubs/trends/documents/2010TrendsES.pdf <http://www.socialinvest.org/resources/research/>, Accessed on 16 November 2010.

Valor, C. and M. de la Cuesta: 2007, 'An empirical analysis of the demand of Spanish religious groups and charities for socially responsible investments', Business Ethics: A European Review, 16(2), 175-190.

Van Buren, H. J.: 2007, 'Speaking Truth to Power: Religious Institutions as Both Dissident Organizational Stakeholders and Organizational Partners', Business \& Society Review, 112(1), 55-72.

Van Cranenburgh, K. C.: 2010, 'Faith Institutions and Impact Investing: An Introduction', International Interfaith Investment Group.

Williams, G. and J. Zinkin: 2010, 'Islam and CSR: A Study of the Compatibility Between the Tenets of Islam and the UN Global Compact', Journal of Business Ethics, 91(4), 519533. 